\title{
NOTES
}

\section{PROFIT RIGHTS AND CREDITORS' PRIORITIES AFTER A PARTNER'S DEATH OR RETIREMENT: SECTION 42 OF THE UPA*}

RETIRING partners or representatives of deceased partners often claim a share of profits from business subsequently undertaken by remaining members of the firm. ${ }^{1}$ When a personal representative or a former partner has consented informally or by assignment, partnership agreement, or will to leave his investment in the business, ${ }^{2}$ he generally has the option of sharing in

*Blut v. Katz, 13 N.J. 374, 99 A.2d 785 (1953).

1. Any retirement of a partner from a general partnership vithout violation of the partnership agreement dissolves the partnership. See, e.g., Fisher v. Fisher, 83 Cal. App. $2 d 357,188$ P.2d S02 (1948) (consent of all partners); Miurray v. Bateman, 315 Mass. 113, 51 N.E.2d 954 (1943) (terminable at will partnership); Ludlum v. Wagner, 212 App. Div. 779, 209 N.Y. Supp. 540 (3d Dep't 1925) (same); Usifouras Partivership Act $\$ 31(1)$ (1949) (hereinafter cited as UPA).

Moreover, it is generally held that a withdrawal, even though in contravention of the partnership agreement, will dissolve the partnership. See, e.g., Aths v. Atha, 303 Mich. 611, 6 N.W.2d $S 97$ (1942); Solomon v. Kirkwood, 55 Mich. 256, 21 N.W. 336 (1884); UPA $\S 31(2)$. However, the partner wrongfully causing dissolution is liable for damages for breach of contract. Burnstine v. Geist, 257 App. Div. 792, 15 N.Y.S.2d 48 (1st Dep't 1939); UPA $\$ 3 \$(2)$ (a) (II). This note does not primarily deal with the problem of a wrongfully dissolved partnership.

A partner's death also dissolves a general partnership. E.g., Darcy v. Int. Rev. Comm'r, 66 F.2d 581 (2d Cir. 1933); Harmon v. Miartin, 395 Ill. 595, 71 N.E.2d 74 (1947); UPA § 31 (4); CRANE, Partwership 406-07 (1952).

Dissolution requires the remaining partners to wind up partnership affairs, unless there has been effective consent by the former partner or his personal representative to continuation of the business. E.g., Mellon v. Heiner, 14 F. Supp. 424 (W.D. P3. 1936); Mosher v. Lount, 29 Ariz. 267, 240 Pac. 1027 (1925); Dizl v. Mrartin, 37 S.W.2d 166 (Tex. Civ. App. 1931) ; UPA §38(1). "Winding up" refers to the liquidation of partnership assets, the payment of partnership debts, and the distribution to partners of the cash value of their partnership interests. See UPA \$29, Commissioner's Note; Curre, PArTNERSHIP 429 (1952).

2. See Hoyt v. Sprague, 103 U.S. 613 (1881) (informally); Adams \& Co. v. Albert, 155 N.Y. 356, 49 N.E. 929 (1898) (same); Is re Rudy, 25 F. Supp. 912 (W.D. Ky. 1939) (assignment); In re Hess, 1 F.2d 342 (W.D. Pa 1923) (same).

The partnership agreement may provide that the remaining partners shall purchase, or have an option to purchase, the interest of the deceased or retired partner. Sce Murphy v. Mrurphy, 217 Mass. 233, 104 N.E. 466 (1914); cf. MIcKinnon v. MrcKinnon, 56 Fed 409 (Sth Cir. 1893) ; Harbster's Appeal, $125 \mathrm{~Pa} .1,17$ Atl. 204 (18S9). Or it may simply provide that the executor of a deceased partner leave the decedent's interest in the business for a specified period. See Wild v. Davenport, 4 S N.J.L. 129, 7 Atl. 295 (1885); Stewart v. Robinson, 115 N.Y. 32S, 22 N.E. 160 (18S9).

Consent may also be given by will of a deceased partner. The will may parmit or direct the executor to continue the estate's investment position in the dissolved gartner- 
earnings or taking interest on his fund. ${ }^{3}$ But when the remaining partners use his investment without consent, the withdrawing member may be able to obtain no more than interest. ${ }^{4}$ Moreover, when the erstwhile partner or his personal representative finally decides to withdraw his holdings, creditors of the business often claim priority over him. ${ }^{5}$ If the creditors loaned money before death or retirement of the firm member, their claims clearly outrank his. ${ }^{6}$ And new creditors have precedence if they have not received proper notice. ${ }^{7}$ But when new creditors have notice, priority apparently depends upon the withdrawing member's having consented to continued use of his funds. ${ }^{8}$

In the recent case of Blut v. Katz, ${ }^{9}$ the New Jersey Supreme Court interpreted Section 42 of the Uniform Partnership Act, which deals with both the

ship's continuing business rather than force a liquidation. See In $r \varepsilon$ Lough, 182 Fed. 961 (2d Cir. 1910) ; Kilhoffer v. Zeis, 109 Misc. 553, 179 N.Y. Supp. 523 (Sup. Ct. 1919).

Either the will or the partnership agreement may provide for the introduction of a new partner as a representative of the deceased or retired partner. See Andrews v. Stinson, 254 I1l. 111, 98 N.E. 222 (1912) (will) ; Matter of Marx, 106 App. Div. 212, 94 N.Y. Supp. 151 (2d Dep't 1905) (agreement); McGrath v. Cowen, 57 Ohio St. 385, 49 N.E. 338 (1898). This is not the kind of consent here referred to, since in such a situation the successor partner's undisputed right to share in profits is grounded on ordinary partnership principles.

3. See notes 19 and 20 infra. For a complete discussion of the cffects of various arrangements for continuation of a business after the death of a partner, see Fuller, Partnership Agreements for Continuation of an Enterprise After the Death of a Partner, 50 YaLe L.J. 202 (1940). See also Adelman, The Power to Carry on the Business of a Decedent, 36 MrCH. L. REv. 185, 186 (1937).

4. See text at note 16 infra.

5. See page 714 infra.

6. In re Hess, 1 F.2d 342 (W.D. Pa. 1923) ; Adams \& Co. v. Albert, 155 N.Y. 356, 49 N.E. 929 (1898); Kilhoffer v. Zeis, 109 Misc. 555, 179 N.Y. Supp. 523 (Sup. Ct. 1919); see Big Four Implement Co. v. Keyser, 99 Kan. 8, 12-13, 161 Pac. 592, 594 (1916). To hold otherwise would be to allow such a retired or deceased partner to compete with his own creditors. Section 42 and $41(8)$ of the Uniform Partnership Act codify this priority. See note 11 infra.

7. Only legally sufficient notice to such creditors can terminate the apparent authority of the remaining partners to act for the old partnership and to thereby bind the retiring partner or the estate of the deceased partner. See, e.g., Torvend v. Patterson, $136 \mathrm{Cal}$. App. 120, 28 P.2d 413 (1933) ; McNeil Co. v. Hamlet, 213 Ill. App. 501 (1919); Security State Bank v. Nelson, 171 Minn. 332, 214 N.W. 51 (1927); Schwartz Bros. \& Co. v. Beacham, 157 Miss. 93, 127 So. 689 (1930) ; Kersch v. Machover, 194 N.Y. Supp. 239 (Sup. Ct. 1922); UPA §35; CrANe, PARTNERShIP 428-42 (1952). At common law, the general rule is that no special notice is required upon dissolution by death of a partner. See, e.g., National Union Bank of Maryland v. Hollingsworth, 135 N.C. 556, 47 S.E. 618 (1904). However, $\S 35$ of the Uniform Partnership Act provides that notice of most types of dissolution, including dissolution by death, must be given directly to those without actual knowledge who extended credit to the old partnership. New creditors who were not also creditors of the old partnership may be notified by newspaper publication.

8. See text at notes 27 and 30 infra.

9. 13 N.J. 374,99 A.2d 785 (1953). 
right of a former partner to share in the profits of a continued business and his relation to firm creditors. ${ }^{10}$ In this case the remaining members of a manufacturing enterprise pursued the business without consent of either the deceased partner or his executrix. Section 42 gives a deceased or retired partner an "ordinary" creditor's right to "the profits attributable to the use of his right in the property of the dissolved partnership" when the business is continued with his consent. ${ }^{11}$ The Act does not specifically deal with such part-

10. The Uniform Partnership Act has been adopted in the following states: Arlansas, 6 ARK. Stats. Axn. $\$ \$ 65-101-65-143$ (1947); Colorado, Colo. Stats. Azz. c 123, $\S \S 1-43$ (1935); Delaware, 3 Des. Code ANN. tit. 6, \$\$ 1501-1543 (1953); Idaho, 9 Inano CODE $\$ \S 53-301-53-343$ (1937) ; Illinois, ILL. ANN. STATs. c. 106行, $\$$ 1-43 (Smith-Hurd, 1952) ; Maryland, 2 ANN. Code Mfo. Art. 73A, \$\$1-43 (1951); Massachusetts, 3 Azz:. Laws MIAss. c. 108A, $\$ 11-44$ (1946) ; Michigan, 14 MIcr. STATs. Aws. $\$ \$ 20.1-20.43$ (1937) ; Minnesota, 21 Mins. Stats. ANN. \$\$323.01-323.43 (1945); Montana, 4 Rev. Cone Mont. $\$ \S 63-101-63-606$ (1947) ; Nebraska, Rev. Stats. Ne及 $\$ \S 67-301-67-343$ (1943) ; Nevada, Nev. Coxip. Laws $\$ \S 5028-5028.43$ (Supp. 1931-1941); New Jersey, N.J.S.A. $\$ \S 42: 1-1-42: 1-43(1940)$; New Mexico, 5 N.M. Srurs. Amr. $\$ \S 70-116-70-$ 158 (Supp. 1951); New York, N.Y. Partanersuip LAW $\$ \$ 1-74$ (1948); North Carolina, Gen. Stats. N.C. \$§59-31-59-73 (1950) ; Oregon, 1 Ore. Rev. Stats. \$§ 68.010-6\$.650 (1953) ; Pennsylvania, Pa. Srat. Ans. tit. 59, $\$ 11-105$ (Purdon, 1930); South Dalsota, 3 S.D. Code $\$ \S 49.0101-49.0515$ (1939); Tennessee, 5 Tens. Cone Azx. $\$ \$ 7841-78 \$ 2$ (Williams, 1934) ; Utah, 5 UTAR ConE ANN. $\$ \S 48-1-1-48-1-40$ (1953); Vermont, VT. Stats. $\$ \$ 6062-6105$ (1947) ; Virginia, 7 VA. CODE $\$ \S 50-1-50-43$ (1950); Washingtón, 4 Rev. CODE WASH. $\$ \$ 25.0425 .08$ (1952); Wisconsin, WIS. STATs. $\$ \$ 123.01-123.38$ (1951); Wyoming, Wyo. Courp. Stats. \$§ 61-101-61-615 (1945).

11. Section 42 states: "When any partner retires or dies, and the busiress is continued under any of the conditions set forth in section $41(1,2,3,5,6)$, or section $38(2 b)$ without any settlement of accounts as between him or his estate and the person or partnership continuing the business, unless otherwise agreed, he or his legal representative as against such persons or partnership may have the value of his interest at the date of dissolution ascertained, and shall receive as an ordinary creditor an amount equal to the value of his interest in the dissolved partnership with interest, or, at his option or the option of his legal representative, in lieu of interest, the profits attributable to the use of his right in the property of the dissolved partnership; provided that the creditors of the dissolved partnership as against the separate creditors, or the representative of the retired or deceased partner, shall have priority on any claim arising under this section, as provided by section $41(8)$ of this act."

Paragraphs 1 and 2 of $\$ 41$ deal with the continuation of a business after assignment by a retired partner of his interest to one or more of the new firm members. Paragraph 3 refers to such business continuation after consent by the personal representative of a deceased partner. Paragraph 5 and $\$ 3 \$(2 \mathrm{~b})$ cover pursuance of the business after 3 wrongful dissolution. And paragraph 6 of $\$ 41$ deals with continuance of the enterprise after the expulsion of a partner. It appears that this paragraph refers only to rightiul expulsion, since if the partner were wrongfully expelled his claim to profits would not be governed by $\$ 42$. It would be measured instead under the original partnership agreement on the theory of a "continuing partnership." Nuland v. Pruyn, 99 Cal. App. 2d 603, 222 P.2d 261 (1950).

Section 41 was designed to insure creditors of the dissolved partnership of also being creditors of a new business arising from a continuation of the old partnership business without liquidation of its debts. See UPA $\S 41$, Commissioner's Note. Under common 
ner's rights absent consent. ${ }^{12}$ Nevertheless, the executrix argued for a broad construction of Section 42 in demanding payment of her testator's investment and a portion of profits earned after his death. ${ }^{13}$ The New Jersey court reasoned that under this section the quid pro quo of a share in profits is the subjection of the retired or deceased partner's interest to the risk of new creditors' claims. ${ }^{14}$ Since the court believed that consenting partners alone assume this risk, ${ }^{16}$ it granted only the value of the non-consenting partner's investment plus interest to his executrix.18

law there is danger that such creditors might be considered merely personal creditors of the old partners. However, a promise to pay such old creditors is often implicd. Sec Lewis, The Uniform Partnership Act, 24 Y ALE L.J. 617, 634-6 (1915).

12. Only paragraphs 1,2 and 3 of $\$ 41$ deal with retiring or deceased partners, and consent to continuation is required in these two situations. See note 11 supra.

13. She could have requested interest on the value of her testator's investment, since $\$ 42$ follows the common law by giving the option of receiving such interest instead of profits. E.g., Kimball v. Baxter, 67 Cal. App. 635, 228 Pac. 381 (1924); In re MeMillan's Estate, 38 N.M. 347, 33 P.2d 369 (1934) ; Brown's Appeal, 89 Pa. 139 (1879). The purpose of this option is to place the risk of loss upon the partner continuing the business. See In re Eisenlohr's Estate, 258 Pa. 431, 435, 102 At1. 115, 116 (1917). Presumably the enterprise was quite profitable in Bhut, and hence a share in profits was more desirable to the executrix.

14. Blut v. Katz, 13 N.J. 374, 379-80, 99 A.2d 785, 787-8 (1953). An alternative ground for the decision appears to be the theory that the profits involved were due main$1 y$ to the "skill, time, and diligence of the remaining partners." Id. at 381,99 A.2d at 788. There is some support for this principle. See note 19 infra. However, since no evidence was introduced indicating otherwise, presumably the profits arose from the sale of hats manufactured by the partnership. And it is difficult not to conclude that one substantial source of these profits was the deceased partner's interest in the physical assets of the partnership. The alternative argument appears even less tenable in view of the court's decision that the executrix was entitled to a sum representing the decedent's interest in good will at the time of dissolution. The value of the good will was measured, at least in part, by the profit-making potential of the business. See id. at 383, 99 A.2d at 789. Hence it is somewhat inconsistent to conclude that the decedent's interest in good will did not contribute substantially to the profits earned after dissolution.

15. Id. at 379-80, 99 A.2d at 787-8. One premise of the decision seems to be that $\S 42$ is limited to those fact situations enumerated in $\$ 41$. See $i d$. at 380,99 A.2d at 787-8. Accordingly, the New Jersey court would probably not require consent as a condition precedent in the case of a partner wrongfully causing a dissolution or a partner rightfully expelled from a partnership. These cases are covered by paragraphs 5 and 6 of $\S 41$, which do not mention consent. See note 11 supra. But it is very doubtful that the interest of such non-consenting partners could be held liable to the claims of new creditors who had notice of dissolution. Yet they are clearly entitled to share in profits under $\$ 42$.

16. The court could have held the claim for profits valid and still have limited its extent. A large share of the profits could have been allotted to the continuing partners as "reasonable compensation." See Tucker v. Tucker, $370 \mathrm{~Pa} .8$, 87 A.2d 650 (1952) (alternative holding); Bracht v. Connell, 313 Pa. 397, 170 At1. 297 (1933). Furthermore, the right to share in profits could have been confined to the nine months following dissolution, since at the end of that period the surviving partners, with the consent of the executrix, deposited in court a sum approximately sufficient to cover her claim. At common law the setting aside of a fund equal to the value of the former partner's interest has been 
This interpretation of Section 42 is both unprecedented and undesirable.17 Without a clear legislative mandate, ${ }^{18}$ the New Jersey construction discards the common law doctrine under which a former partner normally receives profits or interest at his option whether the business is continued with or without consent. ${ }^{19}$ All other courts considering Section 42 have construed

held to terminate the right to share in any profits subsequently earned, apparently on the theory that there can be no unjust enrichment if the property is not used by the surviving partner. Iis re Míaloney's Estate, $233 \mathrm{~Pa} .614,82$ Atl. 958 (1912). And in construing $\$ 42$ a court has treated the consent of the claimant to a setting aside of such a sum as an election by the claimant to take interest rather than profits. Underdown $\mathrm{v}$ Underdown, $279 \mathrm{~Pa} 4 \$ 2,124$ Atl. 159 (1924).

17. There are no cases interpreting $\S 42$ which support the "exposure to risk" theory of Blut, see note 20 infra. And only one common law decision states the principle. Sce Taylor v. Hutchinson, 25 Gratt. 536 (Va. 1S74). This holding is just as readily explicable under the unjust enrichment theory, however, since at the date of dissolution the claimant was indebted to the partnership to such an extent that he had no valuable partnership interest which might be used to earn profits.

18. While there is justification in the language of $\$ 42$ for deciding that it was not meant to apply to non-consent situations, see note 11 supra, there is little justifieation for interpolating the word "only" into the section to make it read: "Only [W] hen . . . the business is continued under any of the conditions set forth in $\$ 41 . . . "$ Such an interpretation is in derogation of the well-established common law right to share in profits in non-consent situations, see note $19 \mathrm{infra}$, and an interpretation in accord with the common law is to be preferred unless a contrary construction is compelled by unambiguous language. See, e.g., Martin v. Federal Surety Co., 5S F.2d 79 (Sth Cir. 1932); Cox v. St. Anthony Bank \& T. Co., 41 Idaho 776, 242 Pac. 785 (1925); Palmer v. Sumner, 133 Me. 337, 177 At1. 711 (1935).

19. E.g., Ruppe v. Utter, 76 Cal. App. 19, 243 Pac. 715 (1925) (no consent); Drapkin v. Klebanoff, 5 N.J. Misc. 531, 137 Atl. 432 (Ch. 1927) (same) ; Brown's Appeal, 89 Pa. 139 (1879) (consent) ; see also Philips v. Reeder, 18 N.J. Eq. 95 (1866).

The extent of the former partner's claim to profits is measured by the share of profits due to utilization of his property. King v. Leighton, 100 N.Y. 386, 3 N.E 594 (1835) (profits due to completion of contract after dissolution); Wood v. Wood, $312 \mathrm{~Pa} .374$, 167 Atl. 600 (1933). Thus if the profits are due to the skill and effort of the continuing partner, the former partner may not share in them. Laterra v. Laterra, 134 N.J. Eq. 162, 34 A.2d 289 (1943) (chicken-selling business). And if the former partner had no substantial interest in partnership assets at the time of dissolution, he will have no claim to profits subsequently earned by the continuing partners. Herren v. Harris, $201 \mathrm{Als}$. 577, 78 So. 921 (1918) (cotton brokerage business); Hall v. Watson, 73 Cal. App. 2d 735, 167 P.2d 210 (1946) (former partner in debt to partnership at dissolution); Smith v. Smith, $51 \mathrm{La}$. Ann. 72, 24 So. 618 (1S98) (insurance agency). Where this is not the case, if the business has been continued with cousent the continuing partner may claim a share of the profits as compensation. Littlefield v. Gorton, 65 R.I. 390, 14 A.2d 682 (1.940).

In cases of continuation with consent, there may be an agrecment eliminating the option of taking interest rather than profits and delimiting the former partner's share of profits. No larger share of profits may then be claimed. In re Mlamaux's Estate, $274 \mathrm{~Pa}$. 533, 118 Atl. 441 (1922).

Another common law exception denies the former partner's claim to profits or interest if the delay in a settlement of accounts was due to his unreasonable demands. Philips 
it to reach this common law result, ${ }^{20}$ which is designed to prevent unjust enrichment of remaining firm members. ${ }^{21}$ Furthermore, denying profits to non-consenting former partners would enable remaining partners to gain through a breach of their fiduciary duty to wind up partnership affairs. ${ }^{20}$ Since partners wrongfully causing dissolution are clearly entitled to profits under the Act, ${ }^{23}$ they have, in New Jersey, rights superior to those of a retired partner whose property has been used against his will.

But the interpretation of Section 42 adopted by the other jurisdictions solves one problem by creating another. While it avoids unjust enrichment, it will lead to difficulty when liquidation of the continued business engenders conflict between the claims of former partners and new creditors. Section 42 gives every claimant under it the same status-that of an "ordinary creditor." Accepted principles of statutory interpretation would impart a constant meaning to this term. ${ }^{25}$ Hence, because Section 42 claimants under the majority doctrine include both consenting and non-consenting former partners, conformity with these principles would result in assigning both classes the same creditor position as against new creditors. Such a uniform definition would be inequitable and unprecedented. ${ }^{26}$

It would be unfair to non-consenting former partners to define "ordinary creditor" as one on par with or inferior to new firm creditors. There is no reason for subjecting such a partner's interest to payment of creditors who had notice of dissolution and therefore had no reason to rely on these assets to satisfy their claims. The common law avoids this result by making the

v. Reeder, supra (alternative holding, denies profits, grants interest); Randolph v. Inman, 172 Ill. 575, 50 N.E. 104 (1898) (denies both interest and profits).

And the continuing partner's exercise of a partnership agreement option to purchase the former partner's interest may cut off the right to share in profits subsequently carned. Hull v. Cartiedge, 18 App. Div. 54, 45 N.Y. Supp. 450 (2d Dep't 1897); Harbster's Appeal, 125 Pa. 1, 17 At1. 204 (1889). See note 2 supra.

20. Vanderplow v. Fredricks, 321. Mich. 483, 32 N.W.2d 718 (1948) (non-consenting former partner after dissolution by notice) ; M. \& C. Creditors Corp. v. Pratt, 172 Misc. 695, 17 N.Y.S.2d 240 (Sup. Ct.), aff'd without opinion, 255 App. Div. 838, 7 N.Y.S.2d 662 (1st Dep't 1938), aff'd without opinion, 281 N.Y. 804, 24 N.E.2d 482 (1939) (no consent by personal representative); Spivak v. Bronstein, 367 Pa. 70,79 A.2d 205 (1951) (ineffective consent by executrix); Bracht v. Connell, $313 \mathrm{~Pa} .397,170$ Atl. 297 (1933) (non-consenting former partner after dissolution by consent); sec Moseley v. Moseley, 196 F.2d 663, 666 (9th Cir. 1952) ; Cahill v. Haff, 248 N.Y. 377, 380, 162 N.E. 288, 289 (1928).

21. See, e.g., Ruppe v. Utter, 76 Cal. App. 19, 25, 243 Pac. 715, 717 (1925) ; Fleming v. Fleming, 211 Idaho 1251, 1271-2, 230 N.W. 359, 368 (1930) ; Losch v. Marcin, 251 N.Y. 402, 410, 167 N.E. 514, 516 (1929) ; King v. Leighton, 100 N.Y. 386, 393, 3 N.E. 594, 597 (1885); In re Eisenlohr's Estate, 258 Pa. 431, 437, 102 Atl. 115, 116 (1917).

22. See note 1 supra.

23. UPA $\S 81(5)$ and 42 . See note 11 supra.

24. See note 11 supra.

25. See, e.g., Helvering v. Credit Alliance Corp., 316 U.S. 107, 111 (1942); Unitcd States v. Raynor, 302 U.S. 540, 547 (1938).

26. See pages 714-15 infra. 
claims of non-consenting retired or deceased partners superior to those of such creditors. ${ }^{27}$

On the other hand, whenever a consenting former partner is involved, it would be unfair to new business creditors to define "ordinary creditor" as one superior to them. ${ }^{28}$ The common law with good reason regards a partner who has assigned his interest to only one of the remaining partners as a personal creditor inferior to all business creditors, since he was willing to rely solely upon the individual credit of that firm member. ${ }^{29}$ And even if the erstwhile partner assigns his interest to the firm as a whole, an intent to submit his investment to the risks of the new business may be reasonably inferred. One line of common law cases adopts this position by making such consenting former partners inferior to new creditors. ${ }^{30}$ And, in any event, no court has gone further than putting consenting partners and new creditors on par. ${ }^{31}$

Thus both the New Jersey and the majority rules are unsatisfactory, though for different reasons. The New Jersey decision denies Section 42 "profitoption" rights to non-consenting former partners but grants them to consenting former partners. Accordingly, only the latter need be termed "ordinary

27. Hurst v. Smith, 227 Ala. 664, 151 So. $\$ 25$ (1933); Giddens v. Reddoch, 207 Ala. 297, 92 So. 848 (1921). Such partners have a lien on partnership property. See Reynolds v. Roberts, 119 Kan. 281, 237 Pac. 931 (1925); Burk v. Burk, 128 S.W. 315 (Ct. App. Ky. 1910).

28. This definition has already been given the term "ordinary creditor" in a case involving a claim under $\$ 42$ to share in profits made by continuation of the business without consent. Froess v. Froess, 284 Pa. 369, 131 Atl. 276 (1925); id., 239 Pa 69, 137 Atl. 124 (1927). See Crane, Partinership 463 n.43 (1952); 74 U. of PA. L. Rew. 512 (1926).

29. The question of the partner's reliance is one of intent to be ascertained from facts such as the wording of the continuation agreement and the treatment of the debt on the books of the business. In re Strauss, 9 F.2d 792 (7th Cir. 1925); Reed v. Dunlop, 280 Fed. 380 (Sth Cir. 1922) ; In re Lough, 182 Fed. 961 (2d Cir. 1910) ; In re Hess, 1 F2d 342 (W.D. Pa. 1923). But see Hoyt v. Sprague, 103 U.S. 613, 628 (18s0); Is re Rudy, 25 F. Supp. 912 (W.D. Ky. 1939) senble.

30. Hoyt v. Sprague, 103 U.S. 613 (1880) ; Big Four Implement Co. v. Keyser, 99 Kan. \&, 161 Pac. 592 (1916) ; Adams \& Co. v. Albert, 155 N.Y. 356, 49 N.E. 929 (1898); Kilhoffer v. Zeis, 109 Misc. 555, 179 N.Y. Supp. 523 (Sup. Ct. 1919).

But the presumption is that a deceased partner did not intend his entire estate to be subject to the risks of a continued business, even though he consented to its continuation without liquidation. New creditors, therefore, generally may attack only the value of his old partnership interest. Smith v. Ayer, 101 U.S. 320 (1879); Burwell v. Mandeville's Ex'r, 2 How. 559 (U.S. 1844) ; Stewart v. Robinson, 115 N.Y. 328, 22 N.E. 160 (18S9); Kilhoffer v. Zeis, stpra; Wilcox v. Derickson, $168 \mathrm{~Pa}$. 331, 31 Atl. 1080 (1895). The presumption may be rebutted by a clear indication of an intent to subject the entire estate to claims of new creditors. Accord, Willis v. Sharp, 113 N.Y. 586, 21 N.E. 705 (1889) (executor carried on individual proprietorship).

31. It has been held that a former partner's claim will be on par with those of new creditors if the former partner has not led such creditors to reasonably believe that their claims could be satisfied from his investment. In re Lough, 182 Fed. 961 (2d Cir. 1910) (appeared on books as loan upon which interest was paid); accord, Smith v. Ayer, 101 U.S. 320 (1879). 
creditors." Therefore the application of the New Jersey rule would not involve assigning the same creditor position to both consenting and non-consenting former partners. However, the New Jersey rule does prevent the former partner's participation in profits earned by the unauthorized use of his property. The majority rule avoids this difficulty, but threatens to work injustice to either the former partner in non-consent cases or to creditors of the new business in consent situations, depending upon the definition of "ordinary creditor" adopted. ${ }^{32}$

The disadvantages of both positions can be avoided by applying Section 42 only when the former partner consents to a continuation of the business and dealing with non-consenting deceased or retired partners under the common law. ${ }^{33}$ The clear import of the words of Section 42 suggests this approach. ${ }^{34}$ Moreover, it appears to have some judicial support. ${ }^{36}$ While eliminating the danger of unjust enrichment of the remaining partners, it would at the same time cope with the creditor problem by placing non-consenting deceased or retired partners outside the scope of Section $42 . .^{36}$ Thus the term "ordinary creditor" would refer only to consenting former partners. This would avoid giving such partners unwarranted preference over new firm creditors. ${ }^{37}$ And such interpretation of Section 42 would also grant non-consenting partners their deserved priority under the common law.

32. It might be possible for the Pennsylvania court, which has already interpreted "ordinary creditor" as meaning one superior to new firm creditors, see note 28 supra, to avoid difficulty in many future cases involving consenting former partners by holding them estopped from claiming such advantage. It seems probable that facts amounting to an estoppel might be present in many such cases. See note 31 supra.

33. Section 5 of the Uniform Partnership Act provides: "In any case not provided for in this act the rules of law and equity, including the law merchant, shall govern."

34. See note 11 supra.

It would be possible for a court to interpret "ordinary creditor" as one subordinate to new creditors if the business was continued with consent, and superior to new creditors if the business was continued without consent. This, in effect, would be rendering the term "ordinary" meaningless by robbing it of any fixed definition. See text at note 25 supra.

35. See Sibert v. Shaver, 111 Cal. App. 2d 833, 245 P.2d 514 (1952) ; Losch v. Marcin, 251 N.Y. 402, 167 N.E. 514 (1929). Both cases granted claims of the estates of deccased partners to a share of the profits made by continuation of a dissolved partnership's business without consent. Neither case mentions $\S 42$, and yet the Uniform Partnership Act was in effect in both states. CAL. Civ. Cone $\$ \S 2395-439$ (Deering, 1941) (repealed, 1949); N.Y. Partnership Law §§1-78 (1948). See also, Blut v. Katz, 13 N.J. 374, 384-5, 99 A.2d 785, 790 (1953) (partial dissent by Chief Justice Vanderbilt and Justice Heher).

36. The English statute avoids the difficulties involved in $\S 42$ by simply codifying the entire common law doctrine. Thus, there is no limitation of the statute to cases of continuation with consent and no reference to the creditor status of the former partner. Partnership Act, 1890, 53 \& 54 Vict., c. 39. See Manley v. Sartori, 1 Ch. 157 (1927).

37. The resulting inferiority of such partners would be in accord with the intent of the drafters of the statute. See UPA $\$ 41$, Commissioner's Note. 